\title{
3. Gir utforskende arbeidsmåter i naturfag bedre læeringsutbytte?
}

\author{
Nani Teig, Ole Kristian Bergem, Trude Nilsen og Bas Senden
}

Sammendrag Flere internasjonale studier har funnet en positiv sammenheng mellom utforskende arbeidsmåter og elevers læringsutbytte, men nesten ingen studier har tidligere unders $\varnothing$ kt dette med utgangspunkt i representative norske data. Data fra TIMSS 2019-studien ble analysert med flernivå strukturell ligningsmodellering for å undersøke sammenhenger mellom utforskende arbeidsmåter og prestasjoner og motivasjon på 9. trinn. Resultatene viser en sterk sammenheng mellom utforskende arbeidsmåter og motivasjon for naturfag og en middels sterk sammenheng mellom utforskende arbeidsmåter og faglige prestasjoner.

Nøkkelord læringsutbytte | motivasjon | naturfagdidaktikk | TIMSS | utforskende arbeidsmåter

Abstract Several international studies have found a positive relation between inquiry and student learning outcomes, but almost no studies have examined this using representative Norwegian data. Data from TIMSS 2019 was analyzed using multilevel structural equation modeling to estimate relations between inquiry and student performance and motivation in science in Grade 9. The results show a strong relation between inquiry and student motivation for science, and a medium strong relation between inquiry and student achievement.

Keywords student outcomes I motivation I science education I TIMSS I inquiry

\subsection{INNLEDNING}

Utforskende arbeidsmåter har fått mye oppmerksomhet i naturfagdidaktisk forskning og er sterkt anbefalt i læreplanreformer, både internasjonalt og i Norge (AbdEl-Khalick et al., 2004; Knain \& Kolstø, 2019; Minner, Levy \& Century, 2010; Rocard et al., 2007). I læreplanverket Kunnskapsløftet 2006 er utforskende arbeids- 
måter lagt til hovedområdet Forskerspiren. Her slås det fast at naturvitenskap både er «et produkt som viser den kunnskapen vi har i dag», og prosesser «som dreier seg om hvordan naturvitenskapelig kunnskap bygges og etableres» (Udir, 2006, s. 2). Elever skal blant annet lære å utvikle hypoteser, bruke systematiske observasjoner, anvende kritisk tenkning, argumentere og begrunne sine konklusjoner (Udir, 2006). Innenfor naturfagdidaktikk benyttes begrepet 'utforskende arbeidsmåter' for å karakterisere en undervisningsmetode som tar utgangspunkt i disse prosessene (Bybee et al., 2006; Crawford, 2014; Duschl, 2003; Rönnebeck, Bernholt \& Ropohl, 2016). Knain og Kolstø (2019) definerer utforskende arbeidsmåte som en arbeidsmåte som påkaller og øver opp kompetanser i å stille spørsmål og utvikle forslag til svar som underbygges ved hjelp av ulike bevismidler. Muligheten til å engasjere seg i naturfaglige problemstillinger, konstruere egen forståelse og kommunisere ideer er et sentralt aspekt ved denne arbeidsmåten (Furtak \& Penuel, 2019; Minner et al., 2010; Schwab, 1962).

Flere nasjonale forskningsprosjekter har undersøkt hvordan utforskende arbeidsmåter benyttes i norske naturfagklasserom, og hvorvidt dette aspektet ved læreplanen er implementert (se f.eks. Knain, Fredlund \& Furberg, 2021; Ødegaard et al., 2021). Ingen av disse studiene har imidlertid hatt representative utvalg av norske elever. Dermed har de ikke hatt mulighet til å kunne generalisere sine funn til hele den angjeldende populasjonen. Den foreliggende studien er basert på data fra TIMSS. TIMSS har et design med utvalg av hele klasser av elever, og gir et nasjonalt representativt utvalg av elever. Dette åpner opp muligheten for ikke bare å komplementere funnene fra de nevnte forskningsprosjektene med generaliserbare funn, men også undersøke sammenhengen mellom bruk av utforskende arbeidsmåter og elevenes læringsresultater på klassenivå.

TIMSS har gjentatte ganger vist at norske lærere $\mathrm{i}$ et internasjonalt perspektiv i liten grad benytter utforskende arbeidsmåter i naturfag (Martin, Mullis, Foy \& Hooper, 2016; Mullis, Martin, Foy, Kelly \& Fishbein, 2020). Sett i lys av at norske elever på ungdomstrinnet lenge har prestert svakt i naturfag sammenlignet med våre nordiske naboland, og at prestasjonene har gått ned i perioden 2015-2019, er det derfor svært interessant å undersøke sammenhengen mellom utforskende arbeidsmåter og elevers læringsutbytte i naturfag på et representativt utvalg av norske elever.

Elevenes svar på TIMSS-oppgaver i naturfag samt svarene som de gir på spørsmålene i spørreskjemaene, danner grunnlaget for analysene som presenteres i dette kapitlet. Målet er å undersøke sammenhengene mellom bruk av utforskende metoder og elevenes læringsutbytte i naturfag, så vel prestasjoner som motivasjon, og dessuten sammenhengen mellom hvor ofte elever gjør eksperimenter i klassen, og læringsutbytte i naturfag. 
I dette kapitlet stilles følgende forskningsspørsmål:

1. Hva er sammenhengen mellom bruk av utforskende arbeidsmåter og elevenes læringsutbytte i naturfag?

2. Hva er sammenhengen mellom frekvensen av utforskende arbeidsmåter i klassen og elevenes læringsutbytte i naturfag?

\subsection{UTFORSKENDE ARBEIDSMÅTER}

\subsubsection{Hva er utforskende arbeidsmåter?}

Begrepet 'utforskende arbeidsmåter' er mye brukt innenfor naturfagdidaktikk og naturfagdidaktisk forskning, men avgrenses på noe ulike måter i forskjellige studier (Rönnebeck et al., 2016). Likevel synes det klart at en helt sentral idé i denne arbeidsmåten er at elevene skal få mulighet til å tilegne seg egne erfaringer for slik å bygge opp og utvikle sin forståelse av naturfaglige sammenhenger (National Research Council, 2012). Dette skal også gi elevene muligheter til å engasjere seg $\mathrm{i}$ kritisk tenkning og verdsette hvordan naturfaglig kunnskap etableres (Crawford, 2014). En lærer kan bidra til å gi elevene denne type erfaringer gjennom å utfordre dem til å observere, stille spørsmål, formulere hypoteser og planlegge forsøk. Slik kan elevene utvikle viktige kompetanser som gjør at de forstår naturvitenskapens egenart (Lederman, 2019; Lee \& Brown, 2018). Utforskende arbeidsmåter vil derfor framstå som svært elevsentrert læring, i og med at det er elevene selv som utfører de naturfaglige undersøkelsene og eksperimentene. Gjennom bruk av denne metodikken får elevene stillet sin nysgjerrighet til fenomener i omverdenen og får dessuten anledning til å engasjere seg i drøfting av naturfaglige begreper, ideer og prosesser og delta aktivt i gjennomføringen av forsøk (Crawford, 2014; Knain \& Kolstø, 2019). I et klasserom hvor utforskende arbeidsmåter dominerer, vil elevene gjennom sin aktive deltakelse stadig videreutvikle sin naturfaglige kompetanse relatert til hva naturfag er, hva man gjør i naturfag, og hvordan man kommuniserer naturfag (National Research Council, 2000).

Rönnebeck et al. (2016) utførte en systematisk gjennomgang av 96 empiriske studier innen naturfagdidaktikk med søkelys på hvordan utforskende arbeidsmåter var definert. De syntetiserte den ulike forståelsen av dette sentrale begrepet, og lanserte på bakgrunn av dette et rammeverk som inkluderer de ulike fasene denne arbeidsmåten innbefatter. Disse fasene ble beskrevet og gruppert under betegnelsene: forberedelse, gjennomføring, forklaring og evaluering. Modellen som de utviklet, er presentert i figur 3.1. I dette rammeverket forstås kommunikasjon som en 
overordnet kompetanse som er relevant for alle disse tre fasene. Kommunikasjon er essensielt både for å forstå vitenskapelige begreper og prosedyrer og for deltakelse i et vitenskapelig samfunn (Rönnebeck et al., 2016, s. 183). I tillegg anerkjenner dette rammeverket viktigheten av å relatere utforskende arbeidsmåter til elevens forforståelse av vitenskapelige begreper og naturvitenskapens egenart (Rönnebeck et al., 2016).

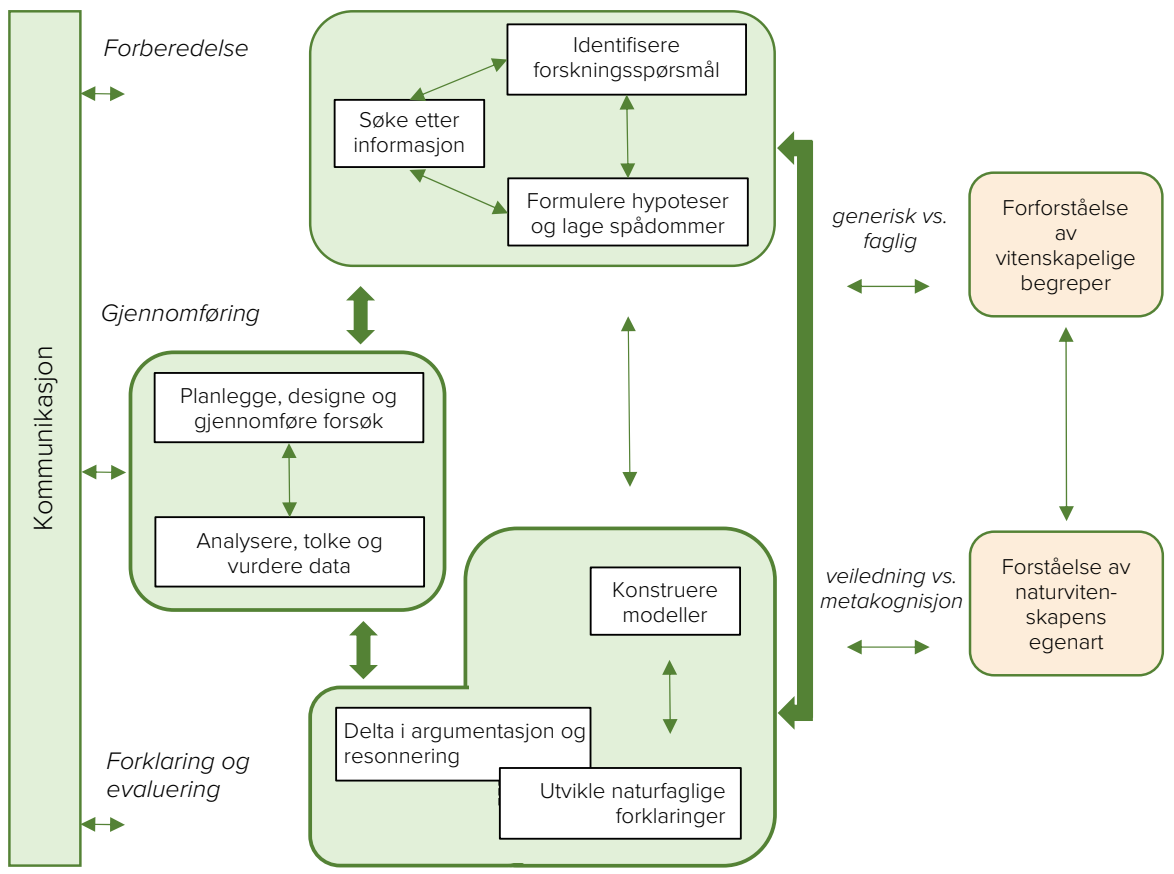

Figur 3.1 Et begrepsmessig rammeverk for utforskende arbeidsmåter i denne studien, oversatt fra Rönnebeck et. al. (2016, s. 189).

Rammeverket for utforskende arbeidsmåter i figur 3.1 er derfor brukt som utgangspunkt for å velge ut de relevante utforskende aktivitetene som analyseres $\mathrm{i}$ denne studien. I modellen som Rönnebeck et al. (2016) utviklet, står spørsmålsformulering, datainnsamling og kunnskapsbygging sentralt $\mathrm{i}$ alle typer av utforskende arbeidsmåter (Knain \& Kolstø, 2019). Det bør også nevnes at dette rammeverket harmonerer godt med hvordan utforskende arbeidsmåter er presentert i de store internasjonale undersøkelsene TIMSS og PISA (Mullis et al., 2020; OECD, 2016), og i norske læreplaner (Utdanningsdirektoratet, 2020) og utdanningsreformer (Kunnskapsdepartmentet, 2010, 2015). 
TIMSS 2019-undersøkelsen har ikke en eksplisitt konseptualisering av utforskende arbeidsmåter. Dette er derimot bakt inn som en essensiell del av konstruktet «undervisningskvalitet», som består av de tre dimensjonene klasseledelse, kognitive utfordringer og støttende loering (Mullis \& Martin, 2017). Utforskende arbeidsmåter er spesielt tett knyttet til kognitive utfordringer, som handler om å gi elevene mulighet til å engasjere seg i utfordrende aktiviteter. Innen naturfag vil dette for eksempel være å gjennomføre et eksperiment, diskutere resultatene fra eksperimentet, og bruke argumentasjon og bevis for å støtte sine konklusjoner (Mullis \& Martin, 2017).

\subsubsection{Utforskende arbeidsmåter og elevenes læring og læringsutbytte i naturfag}

Utforskende arbeidsmåter er en svært sentral del av naturfagundervisningen og har lenge blitt anbefalt både av forskere og innenfor naturfagets interesseorganisasjoner (Abd-El-Khalick et al., 2004; American Association for the Advancement of Science, 1994; Rocard et al., 2007). Utforskende arbeidsmåter framstår i stor grad som unike for naturfagundervisningen, ettersom de i liten grad brukes i andre fag (Teig, Scherer \& Nilsen, 2019). Forskere har argumentert for at utforskende arbeidsmåter harmonerer godt med hvordan elever faktisk lærer naturfag, i og med at denne metodikken i så stor grad vektlegger elevenes forforståelse i utviklingen av deres kunnskap (Crawford, 2014; Rivet \& Krajcik, 2008). I tillegg vil klasserom som vektlegger utforskende metoder, forankre læring i spørsmål som er meningsfulle for elevene, legge til rette for muligheter til å knytte sammen vitenskapelige ideer gjennom bruk av varierte representasjoner, og stimulere elevenes engasjement i den vitenskapelige diskurs (Hubber, Tytler \& Chittleborough, 2018; Krajcik \& Sutherland, 2010). Bruk av utforskende metoder er derfor viktig i relasjon til det overordnete målet om å gi elever en naturfaglig allmenndannelse (scientific literacy). Kjerneelementene er her å stimulere elevenes evner til å tenke kritisk, og til å kunne ta velinformerte beslutninger som aktive deltakere i et demokratisk, globalt fellesskap (Duschl, 2008; Lederman, 2019; Lee \& Brown, 2018; Sadler, Barab \& Scott, 2007).

Å lære naturfag gjennom å delta i undersøkelser legger vekt på elevenes aktive deltakelse og deres eget ansvar for å konstruere sin kunnskap (Constantinou, Tsivitanidou \& Rybska, 2018; Lee \& Brown, 2018; Rönnebeck et al., 2016). Dette aktive, selvstyrende og elevsentrerte aspektet av utforskende arbeidsmetoder gjør at elevene bidrar som deltakere i kunnskapsbygging, i stedet for bare å være passive observatører. Aktiv deltakelse øker forståelsen av hvordan naturfaglig kunnskap 
oppstår (Crawford, 2014; Lederman, 2019; Schwab, 1962). Mer spesifikt kan dette uttrykkes som at utforskende arbeidsmåter stimulerer forståelsen av de ulike domenene av vitenskapelig kunnskap. Disse domenene kan sies å bestå av konseptuell, epistemisk, prosedural og sosial kunnskap (Duschl, 2008; Furtak, Seidel, Iverson \& Briggs, 2012; National Research Council, 2007). Det konseptuelle domenet er den kunnskapen som reflekterer den nåværende forståelsen av naturvitenskapelige systemer, inkludert fakta, begreper, lover og vitenskapelige prinsipper. Elever trenger slik kunnskap for å kunne utføre aktiviteter knyttet til forberedelsesfasen av en aktivitet, som for eksempel å formulere forskningsspørsmål, generere hypoteser og planlegge eksperimenter (Rönnebeck et al., 2016). Det prosedurale domenet beskriver mangfoldet av prosedyrer og praksiser som brukes til å etablere naturvitenskapelig kunnskap. Dette domenet er spesielt viktig i gjennomføringsfasen av en aktivitet. Elevene må for eksempel lære å manipulere én variabel om gangen for å gjennomføre eksperimenter (Rönnebeck et al., 2016). Det epistemiske domenet benyttes til å utvikle og evaluere naturvitenskapelig kunnskap. Dette domenet er integrert i de forskjellige fasene av utforskende arbeidsmåter (Duschl, 2008; Furtak et al., 2012). For eksempel bør elevene lære å reflektere over de ulike trinnene i et forsøk; hvorfor ulike prosedyrer brukes, hva som er gyldig argumentasjon og resonnement, og hvilke evalueringer som kan gjøres i relasjon til bruk av sikre kilder og nettsteder. Det sosiale domenet inkluderer interaksjoner som former hvordan naturvitenskapelig kunnskap kommuniseres, representeres, argumenteres og diskuteres (Duschl, 2003, 2008; Furtak et al., 2012). Som vist i figur 3.1 er alle faser av utforskende arbeidsmåter knyttet til vitenskapens sosiale domene gjennom elevenes kommunikasjonskompetanse (Rönnebeck et al., 2016; Rönnebeck, Nielsen, Olley, Ropohl \& Stables, 2018). Gjennom deltakelse i de forskjellige fasene av utforskende arbeidsmåter vil elevene opparbeide en dypere forståelse av naturlige fenomener (Blanchard et al., 2010; Haug \& Ødegaard, 2014; Rönnebeck et al., 2016). Dette skjer fordi de tar i bruk de ulike domenene av naturvitenskapelig kunnskap og praksiser (Duschl, 2008; Furtak et al., 2012).

I den nye norske læreplanen legges det stor vekt på 'dybdelæring', at elevene gradvis skal 'utvikle kunnskap og varig forståelse av begreper, metoder og sammenhenger i fag og mellom fagområder' (Utdanningsdirektoratet, 2019). Dybdelæring innebærer at elevene skal oppøves til å reflektere over egen læring og bruke det de har lært 'på ulike måter i kjente og ukjente situasjoner, alene eller sammen med andre' (Utdanningsdirektoratet, 2019). Å implementere aktiviteter relatert til utforskende metoder i klasserommet vil kunne bidra til bedre læringsresultater gjennom at elevene aktivt tar i bruk dypere læringsforståelse (Chin \& Brown, 2000; National Research Council, 2012; Rönnebeck et al., 2018). Elevene blir engasjert i 
å løse utfordrende oppgaver som er meningsfulle for dem (Sadler et al., 2007). Evnen til å løse komplekse og autentiske oppgaver gjennom bruk av utforskende arbeidsmåter utvikler en dypere og mer sammensatt kunnskap og forståelse av naturvitenskapelig kunnskap enn pugging av fakta og prosedyrer (Chin \& Brown, 2000; Crawford, 2014). Gjennom å knytte de utforskende oppgavene til sin egen erfaring og forkunnskap vil elevene i større grad opparbeide forståelsen av læring som en interpreterende prosess (Rönnebeck et al., 2018; Sadler et al., 2007). På denne måten aktiverer utforskende arbeidsmåter kognitive prosesser som stimulerer og utvikler kritisk tenkning (Crawford, 2014; Lee \& Brown, 2018; Teig \& Scherer, 2016). Det gjør elevene i stand til å utvikle høyere ordens kognitive evner, og til å benytte sin dypere naturvitenskapelige kunnskap til å forstå naturfaglige fenomener (Chin \& Brown, 2000; Constantinou et al., 2018).

I løpet av de tre siste tiårene har det blitt publisert resultater fra en rekke studier som har undersøkt effekten av naturfagundervisning som benytter utforskende arbeidsmåter. Disse studiene kan bli gruppert i to: metaanalyser basert på eksperimentell og kvasi-eksperimentell forskning og studier basert på data fra ILSAstudiene (ILSA-International Large Scale Assessment), spesielt TIMSS og PISA. Metaanalysene viser overveiende moderate, positive effektstørrelser for bruk av utforskende metoder (Alfieri, Brooks, Aldrich \& Tenenbaum, 2011; Furtak et al., 2012; Lazonder \& Harmsen, 2016). Furtak et al. (2012) analyserte 37 forskjellige studier og rapporterte en effektstørrelse på 0.50. Andre metaanalyser viser også viktigheten av støtte fra læreren i form av for eksempel tilbakemeldinger, støttestrukturer og gjennomgåtte eksempler for at elevene skal få størst mulig nytte av praksiser basert på utforskende arbeidsmåter (Alfieri et al., 2011; Lazonder \& Harmsen, 2016).

Mens oppsummerende metaanalyser indikerer at utforskende metoder har en positiv effekt på elevenes læringsutbytte, har analyser av data fra ILSA-studiene gitt mer sprikende funn. I en studie av PISA 2006-data hvor flere land inngikk, fant man en positiv korrelasjon mellom frekvensen av utforskende aktiviteter og elevprestasjoner når det $\mathrm{i}$ hovedsak var lagt vekt på modellering og anvendelse, men derimot tilsvarende negative korrelasjoner når en 'hands-on' tilnærming dominerte aktivitetene (e.g., Gee \& Wong, 2012; Lavonen \& Laaksonen, 2009). Lignende funn er rapportert fra analyser av PISA 2015-data av Cairns (2019). I sine analyser av norske data fra TIMSS 2015 fant Teig, Scherer og Nilsen (2018) en kurvelineær sammenheng mellom bruk av utforskende metoder med vekt på naturfaglige eksperimenter og elevprestasjoner på klassenivå. På tross av en sterk relasjon mellom klasserommenes sosioøkonomiske status (SØS) og naturfaglige prestasjoner fant man ingen indikasjoner på at utforskende metoder fungerte ulikt 
i høy-SØS- og lav-SØS-klasser når det gjelder sammenhenger med elevprestasjoner (Teig et al., 2018).

I tillegg til metastudiene og studiene basert på ILSA-data har flere norske prosjekter undersøkt utforskende arbeidsmåter. LISSI-prosjektet (Ødegaard et al., 2021) er primært en longitudinell videostudie, finansiert med midler fra Udir. Her ble seks klasser på barnetrinnet og fem på ungdomstrinnet filmet med ett års mellomrom. LISSI undersøkte hva som kjennetegner klasseromspraksis i naturfag, med fokus på utforskende arbeidsmåter. I tillegg til en sammenheng mellom elevers motivasjon og prestasjoner fant de at «Faglige prestasjoner hadde også positiv sammenheng med kvaliteten på måten læreren forklarte, oppsummerte og gav feedback på, samt at lærer stilte spørsmål som utfordret elevene» (side 7). Når det gjelder dybdelæring, fant de at: «Lærerne rapporterte at det er en klar sammenheng mellom dybdelæring og utforsking» (side 6).

REDE-prosjektet har også undersøkt bruk av utforskende arbeidsmåter i Norge, med vekt på representasjoner i naturfag (Knain et al., 2021). Dette og flere prosjekter har bidratt med verdifull kunnskap innen naturfagdidaktikk, men ingen av dem har undersøkt hvorvidt utforskende arbeidsmåter har en positiv påvirkning på prestasjoner i naturfag (https://www.uv.uio.no/ils/forskning/prosjekter/rede/).

Den presenterte oppsummeringen illustrerer den betydelige variasjonen $\mathrm{i}$ forskningsfunn knyttet til effektiviteten av bruk av utforskende arbeidsmåter. De sprikende funnene fra analyser av ILSA-data kan ha flere årsaker. For det første: Når man skal undersøke effekter av utforskende arbeidsmåter, er det svært viktig å velge det riktige analysenivået. Når det gjelder analyser av effekten av konstrukter på klasseromsnivå, bør klassen benyttes som analysenivå (for en omfattende gjennomgang av denne tematikken, se Marsh et al., 2012). Mange studier tar ikke hensyn til denne analytiske tilnærmingen og analyserer relasjoner mellom utforskende arbeidsmåter og elevers læringsutbytte bare på ett nivå, for eksempel på elev-, skole- eller landsnivå. I den foreliggende studien benyttes derfor en flernivåmodell, slik at bruk av utforskende arbeidsmåter kan analyseres både på elev- og klassenivå. For det andre: En stor del av litteraturen om effektiv undervisning bygger på antakelsen om at det er en lineær sammenheng mellom utforskende arbeidsmåter og elevers læringsutbytte (Aditomo \& Klieme, 2020; Gee \& Wong, 2012; Lavonen \& Laaksonen, 2009). Flere nyere studier viser imidlertid at dersom hyppigheten av utforskende metoder med vekt på naturfaglige eksperimenter måles for eksempel i antall uketimer, vil det også kunne finnes ikke-lineære sammenhenger (Cairns, 2019; Oliver, McConney \& Woods-McConney, 2019; Teig et al., 2018). På bakgrunn av disse forskningsfunnene vil den foreliggende studien undersøke både lineære og ikke-lineære 
sammenhenger mellom frekvensen av naturfaglige eksperimenter og elevers læringsutbytte.

\subsubsection{Utforskende arbeidsmåter og elevenes motivasjon for naturfag}

Forskning på motivasjon foregår innen flere fagområder og er et bredt og omfattende forskningsfelt. Innenfor utdanningsforskning er interessen for dette temaet særlig knyttet til elevenes motivasjon for å delta i ulike typer fagrelaterte aktiviteter (Eccles \& Wigfield, 2002). Indre motivasjon er her et sentralt begrep som defineres som det å delta i en aktivitet på grunn av den tilfredsstillelsen dette gir, og ikke på grunn av utenforliggende faktorer (Ryan \& Deci, 2000, 2020). Man deltar altså i aktiviteten fordi dette for eksempel oppleves som positivt, utfordrende, interessant eller tilfredsstiller nysgjerrigheten (Adler, Schwartz, Madjar \& Zion, 2018; Palmer, 2009). For en person drevet av indre motivasjon er derfor læring en type bivirkning av å være involvert i den aktuelle aktiviteten (Palmer, 2009). I naturfag vil elever som liker de aktivitetene som tilbys, som synes aktivitetene er interessante, utfordrende og spennende, være drevet av indre motivasjon (Wu \& Wu, 2020). På den annen side vil elever som deltar i aktiviteter først og fremst på grunn av en potensiell ekstern belønning, for eksempel gode karakterer eller positiv omtale av lærer, anses for å være drevet av ytre motivasjon. Tidligere forskning har vist at indre motivasjon fremmer læring i større grad enn ytre motivasjon (Zhang \& Bae, 2020).

Innenfor pedagogisk og fagdidaktisk teori er det å stimulere elevenes indre motivasjon regnet for å være en sentral oppgave for lærere. Ved å styrke og videreutvikle deres indre motivasjon gjør man elevene i stand til å møte fremtidige utfordringer både i yrkeslivet og som aktive deltakere i samfunnet. Derfor bør styrket indre motivasjon anses for å være en viktig del av læringsprosessene og læringsresultatene i skolens faglige virksomhet (Ryan \& Deci, 2000, 2020). I naturfag er bruk av utforskende arbeidsmåter ansett for å bidra til å styrke og utvikle elevenes indre motivasjon for faget (Aditomo \& Klieme, 2020; Adler et al., 2018; Palmer, 2009).

Forskning viser en overveiende sterk sammenheng mellom utforskende arbeidsmåter og elevers motivasjon for å lære naturfag (e.g., Aditomo \& Klieme, 2020; Adler et al., 2018; Areepattamannil, Cairns \& Dickson, 2020; Wu \& Wu, 2020). Elevenes motivasjon og holdninger anses som viktige for deres kognitive engasjement i utforskende aktiviteter. Selvbestemmelsesteorien (Deci \& Ryan, 2008; Ryan \& Deci, 2000, 2020) benyttes ofte for å forstå de avgjørende faktorene for elevers motivasjon for utforskende aktiviteter. Denne teorien hevder at indi- 
vider har medfødte psykologiske behov for utvikling (Deci \& Ryan, 2008; Ryan \& Deci, 2000, 2020). Disse behovene inkluderer: (1) autonomi, ønsket om å styre egen adferd og være uavhengig, (2) kompetanse, ønsket om mestring gjennom å søke kognitive utfordringer, (3) tilhørighet, ønsket om å utvikle tilknytning og oppleve tilhørighet med andre mennesker (Deci \& Ryan, 2000). Forskning understreker lærerens avgjørende rolle for utvikling av elevers motivasjon gjennom vektlegging av disse tre aspektene i bruk av utforskende aktiviteter, for eksempel gjennom å tilby utfordrende oppgaver, legge til rette for autonomi og mestring og stimulere til sosial interaksjon (Areepattamannil et al., 2020; Crawford, 2014; Palmer, 2009).

\subsection{METODE}

\subsubsection{Data og utvalg}

TIMSS er en internasjonal undersøkelse av elevers kompetanse i naturfag og matematikk på 5. og 9. trinn. Undersøkelsen går hvert 4. år, og Norge har deltatt siden første gang undersøkelsen ble gjennomført i 1995. Av alle internasjonale storskalaundersøkelser er det TIMSS som egner seg best for å undersøke sammenhenger mellom læreres undervisning og elevers prestasjoner. Det er særlig fordi TIMSS velger ut hele klasser av elever. Dette gjør det mulig å undersøke hva som kan forklare variansen mellom klasser, altså hvorfor noen klasser presterer bedre enn andre. I tillegg har TIMSS spørreskjema til både elever, lærere og skoleledere, noe som åpner opp for mange ulike forskningsperspektiver. Blant annet kan elevenes naturfagkompetanse relateres til de deltakende landenes læreplaner. For mer om TIMSS-undersøkelsen, se kapittel 1.

Den foreliggende studien inkluderer et representativt utvalg av elever på 9. trinn som deltok i TIMSS 2019, N= 4575 elever fra 231 klasserom. Den gjennomsnittlige alderen til elevene er 14,7 år, og utvalget består av 49,4 prosent jenter og 50,6 prosent gutter. Prosentandelen av elever som er født utenfor Norge, er 10,8 prosent.

\subsubsection{Variabler og konstrukter}

Alle variablene fra elevspørreskjemaet som er med i studien, er beskrevet i tabell 3.1. Variablene er kodet slik at den høyeste verdien er relatert til det mest positive svaret. For alle variablene ligger 'missing' (manglende data) i intervallet 7,1-9,5 prosent. 
Tabell 3.1 Deskriptiv statistikk av alle variabler i denne studien

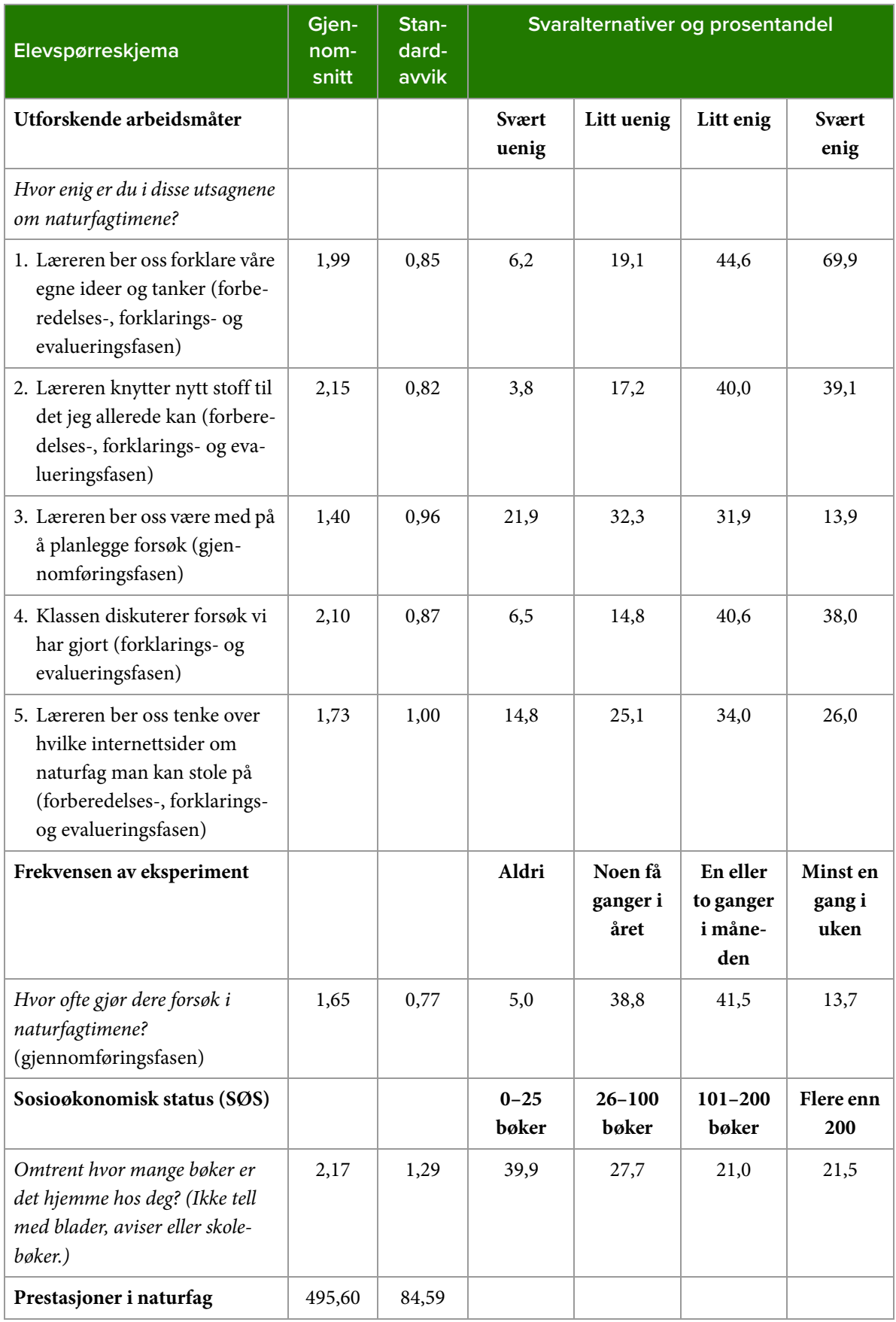




\begin{tabular}{|c|c|c|c|c|c|c|}
\hline \multirow{2}{*}{$\begin{array}{l}\text { Elevspørreskjema } \\
\text { Motivasjon }\end{array}$} & \multirow{2}{*}{$\begin{array}{l}\text { Gjen- } \\
\text { nom- } \\
\text { snitt }\end{array}$} & \multirow{2}{*}{$\begin{array}{l}\text { Stan- } \\
\text { dard- } \\
\text { avvik }\end{array}$} & \multicolumn{4}{|c|}{ Svaralternativer og prosentandel } \\
\hline & & & $\begin{array}{l}\text { Svært } \\
\text { uenig }\end{array}$ & Litt uenig & Litt enig & $\begin{array}{c}\text { Svært } \\
\text { enig }\end{array}$ \\
\hline \multicolumn{7}{|l|}{$\begin{array}{l}\text { Hvor enig er du i disse utsagnene } \\
\text { om naturfag? }\end{array}$} \\
\hline 1. Jeg liker å lære naturfag & 2,01 & 0,85 & 6,6 & 15,5 & 46,5 & 31,4 \\
\hline $\begin{array}{l}\text { 2. Jeg skulle ønske at jeg ikke } \\
\text { var nødt til å lære naturfag }\end{array}$ & 1,85 & 0,97 & 10,0 & 24,5 & 33,9 & 31,6 \\
\hline 3. Naturfag er kjedelig & 1,66 & 0,96 & 23,4 & 31,8 & 32,3 & 12,4 \\
\hline $\begin{array}{l}\text { 4. Jeg lærer mye interessant i } \\
\text { naturfag }\end{array}$ & 2,15 & 0,82 & 4,4 & 13,9 & 43,3 & 38,4 \\
\hline 5. Jeg liker naturfag & 1,95 & 0,90 & 7,5 & 20,4 & 40,4 & 31,7 \\
\hline $\begin{array}{l}\text { 6. Jeg gleder meg til å lære } \\
\text { naturfag på skolen }\end{array}$ & 1,68 & 0,94 & 11,1 & 32,0 & 35,2 & 21,7 \\
\hline $\begin{array}{l}\text { 7. I naturfag lærer jeg hvordan } \\
\text { ting i verden henger sammen }\end{array}$ & 2,20 & 0,77 & 3,5 & 11,4 & 45,2 & 39,8 \\
\hline $\begin{array}{l}\text { 8. Jeg liker å gjøre eksperimen- } \\
\text { ter i naturfag }\end{array}$ & 2,52 & 0,74 & 2,9 & 6,5 & 26,1 & 64,5 \\
\hline $\begin{array}{l}\text { 9. Naturfag er et av de fagene } \\
\text { jeg liker best }\end{array}$ & 1,53 & 1,04 & 19,4 & 29,4 & 28,0 & 22,9 \\
\hline
\end{tabular}

I tillegg benyttes prestasjoner i naturfag som er basert på resultatene fra TIMSS 2019-studien. TIMSS måler elevenes kompetanser i emneområdene biologi, fysikk, kjemi og geofag. I tillegg måler TIMSS tre kognitive områder: (1) å kunne; som innebærer å huske og gjenkjenne fakta, kjenne naturfaglig terminologi og definisjoner, beskrive organismer, stoffer og prosesser, gi eksempler og bruke labutstyr, (2) å anvende; som innebærer å sammenligne og kategorisere, å anvende naturfaglige modeller, knytte faglige begreper og forklaringer til observerte fenomener og tolke informasjon, og (3) å resonnere; som innebærer å analysere naturfaglige problemer, kombinere informasjon, formulere og teste hypoteser, se mønstre i data og trekke konklusjoner, generalisere, begrunne påstander og vurdere ulike alternativer.

Siden ikke alle elever svarer på de samme oppgavene (se kap.1), og for å kunne sammenligne elevenes prestasjoner, bruker man Item Response Theory (IRT) for å generere fem plausible verdier for hver elev (se kapittel 1). I den foreliggende studien benyttes alle fem plausible verdiene i analysene, ut fra anbefalingene som gis i von Davier, Gonzalez og Mislevy (2009). Skalaer for plausible verdier ble etablert 
i den første TIMSS-undersøkelsen i 1995, hvor gjennomsnittet ble satt til 500 og standardavviket til 100 poeng. Mer informasjon om designet for denne studien finnes i teknisk rapport fra TIMSS 2019 (Martin, von Davier, Mullis \& Foy, 2020).

\subsubsection{Analysemetode}

For å undersøke sammenhengen mellom utforskende arbeidsmetoder og elevers prestasjoner i naturfag benyttes 2-nivå (elever og klasser) strukturelle ligningsmodeller (Hox, Moerbeek \& van de Schoot, 2017). For å undersøke reliabiliteten og validiteten til de latente variablene brukes konfirmatorisk faktoranalyse (confirmatory factor analyses). Analyseprogrammet som benyttes, er Mplus versjon 8.5 (Muthén \& Muthén, 1998-2018). Her produseres såkalte faktorladninger, som angir hvor godt hver variabel måler det underliggende konseptet som skal måles av den latente variabelen. Mplus produserer også mål på hvor godt modellen er tilpasset dataene. For å ta høyde for såkalte 'missing' eller manglende data anvendes FIML (Full Information Maximum Likelihood).

Elevers opplevelser i klasserom kan være ulike, og følgelig vil noen elever kunne uttrykke seg mer positivt eller negativt enn andre. Der det benyttes elevsvar, blir disse aggregert til klassenivå, samtidig som det kontrolleres for elevenes svar på elevnivå (se figur 3.2). Dette gjøres for å fjerne støy som kommer av at elevene bedømmer lærerne sine ulikt (Marsh et al., 2012). Slik vil resultatene på klassenivå i denne studien reflektere den delte oppfatningen av utforskende arbeidsmåter og frekvensen av eksperimenter etter å ha justert for irregulariteter i enkeltelevers vurdering (Lüdtke, Trautwein, Kunter \& Baumert, 2007). Figur 3.2 viser en analytisk modell av forholdet mellom utforskende arbeidsmåter og elevprestasjoner på elev- og klassenivå, og at det her kontrolleres for SØS på begge nivåer. For forskningsspørsmål 1 undersøkes sammenhengen mellom utforskende metoder og elevenes prestasjoner og motivasjon. For forskningsspørsmål 2 erstattes utforskende arbeidsmåter med frekvensen av eksperimenter i klassen, og de tilsvarende sammenhengene med elevenes læringsutbytte undersøkes. Ettersom tidligere forskning har indikert at sammenhengene mellom frekvensen av eksperimenter og prestasjoner er kurvelineært (Cairns, 2019; Oliver et al., 2019; Teig et al., 2018), undersøkes muligheten for både lineære og kurvelineære sammenhenger i denne analysen.

Svarene på forskningsspørsmålene i dette kapitlet vil drøftes på klassenivå. Det betyr at det er variansen i elevenes prestasjoner på klassenivå som er relevant, og at det derfor primært er regresjonskoeffisientene på klassenivå som er interessante. 


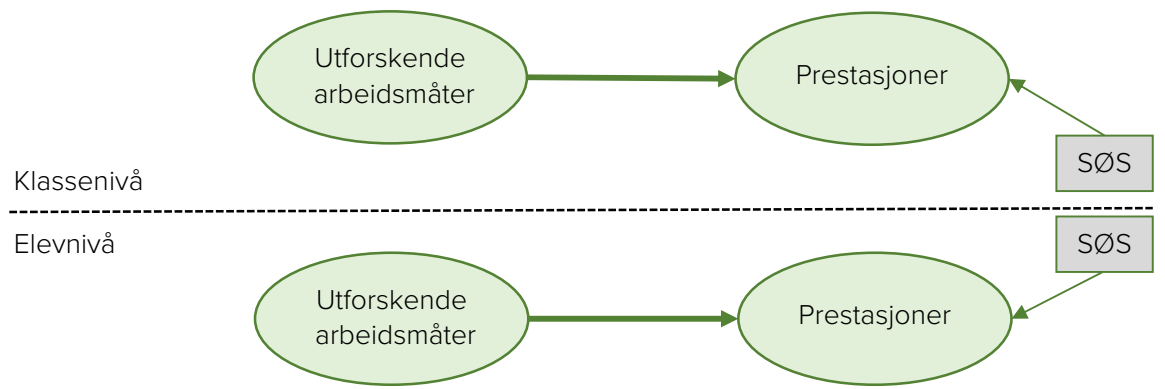

Figur 3.2 En analytisk modell om relasjoner mellom utforskende arbeidsmåter og elevers prestasjoner i naturfag på elev- og klassenivå, korrigert for S $\varnothing \mathrm{S}$ på begge nivåene.

\subsection{RESULTATER}

To latente variabler ble laget, basert på manifeste variabler (se tabell 3.1) målt på elevnivå: utforskende arbeidsmåter og indre motivasjon. Den latente variabelen utforskende arbeidsmåter hadde en reliabilitet på 0,78 på elevnivå, og 0,92 på klassenivå. Den latente variabelen indre motivasjon hadde en reliabilitet på 0,89 på elevnivå, og 0,99 på klassenivå. Intraklasse-koeffisientene for utforskende arbeidsmåter var på 0,12 og 0,72, og for indre motivasjon var de på 0,11 og 0,71 på henholdsvis elev- og klassenivå. For utforskende arbeidsmåter var modelltilpasningene $^{1}$ utmerket med RMSEA $=0,30, \mathrm{CFI}=0,988, \mathrm{TLI}=0,976$, SRMR på elevnivå $=0,019$, og SRMR på klassenivå = 0,036. Modelltilpasningene for indre motivasjon var også god med RMSEA =0,48, CFI =0,967, TLI =0,955, SRMR på elevnivå = 0,033, og SRMR på klassenivå = 0,042. For å oppsummere så hadde begge modellene som ble brukt i denne studien, høy reliabilitet og validitet.

\subsubsection{Sammenhenger mellom utforskende arbeidsmåter og elevenes prestasjoner og indre motivasjon}

Tabell 3.2 viser relasjonene mellom utforskende arbeidsmåter og elevers prestasjoner før det kontrolleres for SØS (nullmodell 1) og etter at det kontrolleres for SØS (modell 1). Tilsvarende viser tabellen relasjonene til indre motivasjon før og etter kontroll for SØS (henholdsvis nullmodell 2 og modell 2). Tabellen inneholder resultater på både elev- og klassenivå. Imidlertid er modellen på elevnivå bare med

1 Se Hu og Bentler (1999) om kriterier til modelltilpasning (model fit) i strukturell ligningsmodellering. RMSEA = Root Mean Square Error of Approximation, CFI = Comparative Fit Index, TLI $=$ Tucker-Lewis-Index, SRMR $=$ Standardized Root Mean Square Residual. 
for å kontrollere for forskjeller mellom elevers svar innen klassene. Derfor vil det her fokuseres mest på resultatene på klassenivå.

Tabell 3.2 Sammenhenger mellom utforskende arbeidsmåter og elevens prestasjoner og indre motivasjon

\begin{tabular}{|l|c|c|c|c|}
\hline \multirow{2}{*}{ Uavhengige variabler } & \multicolumn{2}{|c|}{ Avhengig variabel: Prestasjoner } & \multicolumn{2}{|c|}{$\begin{array}{c}\text { Avhengig variabel: Indre } \\
\text { motivasjon }\end{array}$} \\
\cline { 2 - 5 } & Nullmodell 1 & Model 1 & Nullmodell 2 & Model 2 \\
\hline Elevnivå: & & & & \\
\hline Utforskende arbeidsmåter & $0,012(0,02)$ & $0,011(0,02)$ & $0,469(0,02)^{* * *}$ & $0,461(0,02)^{* *}$ \\
\hline SØS & - & $0,372(0,02)^{* *}$ & - & $0,100(0,02)^{* *}$ \\
\hline Andel av varians $\left(\mathrm{R}^{2}\right)$ & $0,000(0,00)$ & $0,139(0,01)^{* *}$ & $0,220(0,02)^{* * *}$ & $0,223(0,02)^{* *}$ \\
\hline Klassenivå: & & & & \\
\hline Utforskende arbeidsmåter & $0,440(0,15)^{* *}$ & $0,404(0,11)^{*}$ & $0,817(0,06)^{* * *}$ & $0,822(0,06)^{* *}$ \\
\hline SØS & - & $0,544(0,12)^{* *}$ & - & $0,074(0,09)$ \\
\hline Andel av varians $\left(\mathrm{R}^{2}\right)$ & $0,194(0,13)$ & $0,461(0,14)^{*}$ & $0,668(0,10)^{* * *}$ & $0,682(0,09)^{* *}$ \\
\hline
\end{tabular}

Standardiserte regresjonsverdier, standardfeil i parentesene ${ }^{*} \mathrm{p}<0,05,{ }^{* *} \mathrm{p}<0,001$

Sammenhengen mellom utforskende arbeidsmåter og naturfagsprestasjoner på 9. trinn er på 0,440 (standardisert estimat) på klassenivå (tabell 3.2, nullmodell 1). Dette er en middels sterk regresjonskoeffisient, og kan sammenlignes med effektstørrelse i og med at standardavviket er på 100 poeng. Utforskende arbeidsmåter forklarer 19,4 av variasjonen i prestasjoner mellom klasser. Sammenhengen mellom utforskende arbeidsmåter og prestasjoner er ikke signifikant på elevnivå.

Figur 3.3 viser relasjoner mellom utforskende arbeidsmåter og prestasjoner på elev- og klassenivå. etter at det er korrigert for SØS på begge nivåene (tilsvarende tabell 3.2, modell 1). På klassenivå blir relasjonen noe svakere når man kontrollerer for SØS (0,404). Til sammen forklarer utforskende arbeidsmåter og SØS 46,1 prosent av variasjonen i prestasjoner mellom klasser og 13,9 prosent av variasjonen i prestasjoner mellom elever.

Sammenhengen mellom utforskende arbeidsmåter og indre motivasjon er enda sterkere, og standardisert regresjonskoeffisient er på 0,469 på elevnivå og 0,817 på klassenivå, før det kontrolleres for SØS (tabell 3.2, nullmodell 2). Dette er en veldig sterk sammenheng hvor altså utforskende arbeidsmåter forklarer henholdsvis 22 prosent og 66,8 prosent av variasjonen i indre motivasjon mellom elever og klasser. 


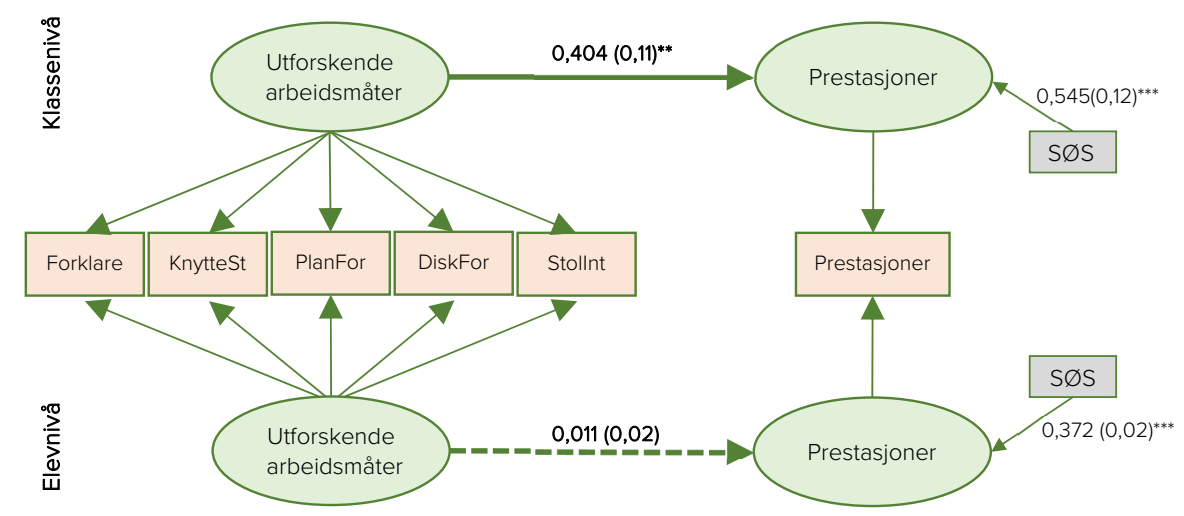

Figur 3.3 Relasjoner mellom utforskende arbeidsmåter og elevers prestasjoner i naturfag på elev- og klassenivå, korrigert for S $\varnothing \mathrm{S}$ på begge nivåene. Forklare = Forklare egne ideer, KnytteSt $=$ Knytte nytt stoff til kunnskap, PlanFor $=$ Planlegge fors $\varnothing k$, DiskFor $=$ Diskutere fors $\varnothing \mathrm{k}$, Stollnt = Stole på internettsider. Se tabell 3.1.

Standardiserte regresjonsverdier, standardfeil i parentesene. ${ }^{*} p<0,10,{ }^{* *} p<0,05,{ }^{* *} p<0,001$

Tabell 3.2, modell 2 viser relasjoner mellom utforskende arbeidsmåter og indre motivasjon på elev- og klassenivå, etter å ha korrigert for SØS på begge nivåene. Når det kontrolleres for SØS både på elev- og klassenivå, blir relasjonen mellom utforskende arbeidsmåter og indre motivasjon på elevnivå mindre $(0,461)$, men forskjellen er ikke signifikant. På klassenivå er det motsatt, og relasjonen blir nå sterkere $(0,822)$, men forskjellen er heller ikke her signifikant. Til sammen forklarte utforskende arbeidsmåter og SØS 22,3 prosent av variasjonen $\mathrm{i}$ indre motivasjon mellom elever og 68,2 prosent av variasjonen $\mathrm{i}$ indre motivasjon mellom klasser.

\subsubsection{Sammenhenger mellom frekvensen av eksperimenter og elevers prestasjoner og motivasjon}

Sammenhengen mellom frekvensen av eksperimenter og naturfagsprestasjoner på 9. trinn er på 0,180 (standardisert estimat) på klassenivå (tabell 3.3, nullmodell 1). Dette er en svak, men signifikant regresjonskoeffisient. Sammenhengen er ikke-signifikant etter å ha kontrollert for SØS (tabell 3.3, modell 1a, lineær modell). 
Tabell 3.3 Sammenhenger mellom frekvensen av eksperimenter og elevens prestasjoner og indre motivasjon

\begin{tabular}{|l|c|c|c|c|}
\hline \multirow{2}{*}{ Uavhengige variabler } & \multicolumn{2}{|c|}{ Avhengig variabel: Prestasjoner } & \multicolumn{2}{|c|}{$\begin{array}{c}\text { Avhengig variabel: Indre } \\
\text { motivasjon }\end{array}$} \\
\cline { 2 - 5 } & Nullmodell 1 & Model 1 & Nullmodell 2 & Model 2 \\
\hline Elevnivå: & & & & \\
\hline Eksperimenter & $0,024(0,03)$ & $0,045(0,03)$ & $0,152(0,02)^{* * *}$ & $0,161(0,02)^{* *}$ \\
\hline SØS & - & $0,379(0,02)^{* *}$ & - & $0,117(0,02)^{* *}$ \\
\hline Andel av varians $\left(\mathrm{R}^{2}\right)$ & $0,001(0,00)$ & $0,144(0,01)^{* *}$ & $0,023(0,01)^{* * *}$ & $0,037(0,01)^{* *}$ \\
\hline Klassenivå: & & & & \\
\hline Eksperimenter & $0,180(0,09)^{*}$ & $0,066(0,09)$ & $0,199(0,10)^{*}$ & $0,196(0,10)^{*}$ \\
\hline SØS & - & $0,525(0,12)$ & - & $0,077(0,11)$ \\
\hline Andel av varians $\left(\mathrm{R}^{2}\right)$ & $0,024(0,03)$ & $0,295(0,13)^{*}$ & $0,040(0,02)$ & $0,051(0,02)$ \\
\hline
\end{tabular}

Standardiserte regresjonsverdier, standardfeil i parentesene. ${ }^{*} p<0,05,{ }^{* *} p<0,001$

Tidligere forskning viser at utforskende arbeidsmåter med vekt på naturfaglige eksperimenter har en kurvelineær sammenheng med elevprestasjoner (Cairns, 2019; Oliver et al., 2019; Teig et al., 2018). Den samme kurvelineære analysen ble utført på dataene i den foreliggende studien, og det ga samme resultat: Etter å ha kontrollert for SØS på elev- og klassenivå (tabell 3.3, model 1b), følger sammenhengene mellom frekvensen av eksperimenter og prestasjoner en kurvelineær eller invertert U-kurve i større grad enn en rett linje. Dette gjelder for begge analysenivåene (se figur 3.4). Det kvadratiske uttrykket for frekvensen av eksperimenter $\left(\right.$ Eksperiment ${ }^{2}$ ) reflekterer den kurvelineære sammenhengen mellom eksperiment og prestasjoner. Den negative regresjonskoeffisienten til det kvadratiske estimatet indikerer at den i utgangspunktet positive sammenhengen mellom frekvensen av eksperimenter og prestasjoner minsker. Det betyr at relasjonen etter hvert blir negativ når frekvensen av eksperimenter øker. Økt bruk av eksperimenter er altså positivt korrelert med høyere prestasjoner opptil et visst nivå, deretter svekkes denne sammenhengen og blir etter hvert negativ.

Tabell 3.3, modell 2 viser relasjoner mellom frekvensen av eksperimenter og indre motivasjon på elev- og klassenivå etter å ha kontrollert for SØS på begge nivåene. Den standardiserte regresjonskoeffisienten på klassenivå var på nesten 0,2 . 


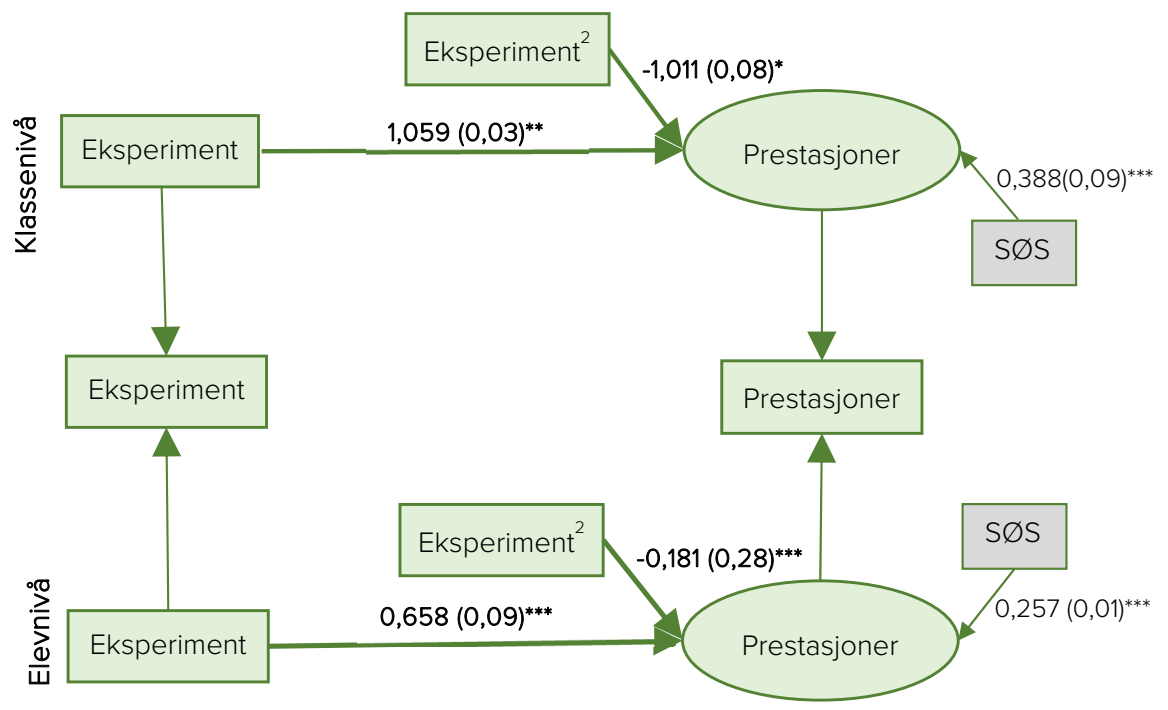

Figur 3.4 En kurvelineær sammenheng mellom utforskende arbeidsmåter og elevers prestasjoner på elev- og klassenivå, korrigert for SØS på begge nivåene.

Standardiserte regresjonsverdier, standardfeil i parentesene ${ }^{*} \mathrm{p}<0,10,{ }^{* *} \mathrm{p}<0,05,{ }^{* * *} \mathrm{p}<0,001$

\subsection{DISKUSJON}

Analysene i den foreliggende studien har gitt følgende hovedfunn:

1. Utforskende arbeidsmåter har en positiv sammenheng med elevenes prestasjoner på klassenivå.

2. Frekvensen av eksperimenter har kurvelineær sammenheng med elevenes prestasjoner både på elev- og klassenivå. Dersom frekvensen av eksperimenter blir for høy, svekkes altså sammenhengen med prestasjoner og blir til slutt negativ.

3. Utforskende arbeidsmåter og frekvensen av eksperimenter har positiv sammenheng med elevenes motivasjon for naturfag både på elev- og klassenivå.

I alle analysene som ligger til grunn for disse resultatene, ble det korrigert for SØS.

\subsubsection{Diskusjon av funn i lys av teori}

Selv om man i studier som benytter tverrsnittsdata fra storskalaundersøkelser, ofte vil være forsiktig med å trekke kausale slutninger (Teig, 2019), viser funnene pre- 
sentert i dette kapitlet en klar positiv sammenheng mellom bruk av utforskende arbeidsmåter og elevenes læringsutbytte. Dette harmonerer godt med resultater fra metaanalyser av denne tematikken (f.eks. Estrella, Au, Jaeggi \& Collins, 2018; Furtak et al., 2012). Ved å anvende rammeverket for utforskende arbeidsmåter utarbeidet av Rönnebeck et al. (2016) synes konseptualiseringen og utvalget av enkeltspørsmål for å måle denne typen undervisning å være i tråd med det som er blitt benyttet i tidligere studier. Dette var mulig fordi Norge i TIMSS 2019-studien inkluderte spesifikke spørsmål i elevspørreskjemaet knyttet til undervisningskvalitet i naturfag.

I studier som undersøker sammenhengen mellom utforskende arbeidsmåter og elevers læringsutbytte, er det viktig å ha reliable og valide mål for begge disse variablene. I TIMSS får elevene oppgaver som dekker fire sentrale fagområder (fysikk, kjemi, biologi og geofag), og tre kognitive domener (å kunne, å anvende, å resonnere). Mange av oppgavene er knyttet til bruk av utforskende arbeidsmåter. Disse oppgavene kan derfor sies å være relatert til begrepet 'dybdelæring', slik dette redegjøres for i teoridelen. Funnene som viser at utforskende arbeidsmåter har en positiv sammenheng med elevenes prestasjoner, indikerer at disse arbeidsmåtene fremmer dybdelæring. Dette er i samsvar med tidligere forskning (Chin \& Brown, 2000; National Research Council, 2012; Rönnebeck et al., 2018).

Den foreliggende studien knytter funn fra storskalaundersøkelser nærmere sammen med anerkjente teorier og funn innen naturfagdidaktikk og naturfagdidaktisk forskning (se f.eks. metaanalyser fra Estrella et al., 2018 og Furtak et al., 2012). Metaanalyser er ofte basert på eksperimentelle studier hvor lærere har blitt spesielt trent opp til å utføre innovative utforskende arbeidsmåter (Aditomo \& Klieme, 2020). I TIMSS måles derimot utforskende arbeidsmåter i vanlige, ordinære timer hvor læreren $i k k e$ har fått slik ekstra opptrening. De presenterte funnene samsvarer godt med tidligere forskningsresultater som indikerer at utforskende arbeidsmåter har en positiv sammenheng med elevenes prestasjoner og motivasjon for naturfag (Furtak et al., 2012; Palmer, 2009; Wu \& Wu, 2020). I tillegg viser den foreliggende studien at naturfagslærere klarer å gjøre utforskende arbeidsmåter meningsfulle og betydningsfulle i vanlige timer, uten spesialtrening i slik undervisning.

Utforskende arbeidsmetoder var positivt relatert til prestasjoner til tross for at variasjonen og mengden av slike aktiviteter var lav på 9. trinn (se tabell 3.1). TIMSS-data viser at det er lite bruk av utforskende arbeidsmåter i Norge i forhold til de fleste andre land (Mullis, Martin, Foy, Kelly \& Fishbein, 2020). Dette kan muligens skyldes at det er relativt få lærere som mottar etter- og videreutdanning, få undervisningstimer i naturfag samt en rapportert mangel på laboratorier og utstyr. Sammenlignet med for eksempel de andre nordiske landene skårer Norge 
lavt på alle disse indikatorene (Kaarstein, Radišić, Lehre, Nilsen \& Bergem, 2020; Mullis et al., 2020). En mulig implikasjon av denne studien er derfor at det burde avsettes mer ressurser til etterutdanning av lærere, ikke minst der utforskende arbeidsmåter blir vektlagt. Dessuten burde en opplæring i bruk av utforskende metoder inngå som en sentral del av lærerutdanningen.

På hvilke måter kan så utforskende arbeidsmåter bidra til elevenes læring? Det å aktivisere elevene i de forskjellige fasene av utforskende arbeidsmåter er viktig for å stimulere elevers begrepsforståelse og styrke deres kunnskap om naturfagets egenart (se figur 3.1). Spesifikt vil de ulike fasene hjelpe elevene til å se sammenhengene mellom de fire domenene av vitenskapelig kunnskap (altså konseptuell, prosedural, epistemisk og sosial) (Duschl, 2008; Furtak et al., 2012). Det konseptuelle domenet av naturfag består av den kunnskapen som reflekterer den foreliggende forståelsen av naturvitenskapelige systemer. Dette inkluderer fakta, begreper, lover og vitenskapelige prinsipper (National Research Council, 2007, s. 26). For å kunne gjennomføre forberedelsesfasen av utforskende aktiviteter, som for eksempel å formulere forskningsspørsmål, generere hypoteser og planlegge eksperimenter, trenger elevene relevant innholdskunnskap om emnet som utforskes. I målene for bruk av utforskende arbeidsmetoder blir elevene blant annet spurt om de får være med på å planlegge forsøk. Dette er relatert til forberedelsesfasen, og her vil elevenes forkunnskaper også spille inn.

Det prosedurale domenet er fundamentalt for å forstå ulike metoder og praksiser brukt får å etablere kunnskap. Lærere bør ta hensyn til prosedyrene i gjennomføringsfasen av utforskende arbeidsmåter, for eksempel elevenes ferdigheter til å manipulere én variabel om gangen for å gjennomføre eksperimenter. Det finnes en god del slike oppgaver i TIMSS. Det hender at elever kan være i stand til å utføre de nødvendige prosedyrene i et eksperiment uten at de evner å reflektere over hvordan de genererer naturvitenskapelig kunnskap. Dette kan være noe av grunnen til den kurvelineære sammenhengen mellom frekvensen av eksperimenter og prestasjoner. Det å gjøre eksperimenter hver eneste time vil ikke nødvendigvis øke elevenes forståelse. Tid til naturfaglig refleksjon og diskusjon må også prioriteres.

Det å reflektere over hvordan naturvitenskapelig kunnskap genereres, er spesielt adressert i det epistemiske domenet. Dette inkluderer forståelse av hvorfor visse prosedyrer brukes til å drive vitenskap, legitimiteten til kunnskapskrav generert fra denne praksisen, og skillet mellom forskjellige typer kunnskapskrav (f.eks. fakta, teori, hypotese og data). Det epistemiske domenet behandles også i de forskjellige fasene av utforskende arbeidsmåter (Duschl, 2008; Furtak et al., 2012), for eksempel i forklarings- og evalueringsfasen. Her kan elevene blant annet inkluderes ved at de får i oppgave å argumentere for sin evaluering av hvilke nettsteder man bør 
stole på. Dette er for øvrig inkludert i et av spørsmålene som måler den latente variabelen, «utforskende arbeidsmåter».

Alle faser av utforskende arbeidsmåter representerer vitenskapens sosiale domene, gjennom elevenes kommunikasjonskompetanse (Duschl, 2008; Furtak et al., 2012). Under gruppearbeidet deltar studentene i utforskende samtaler for å oppnå delt forståelse, forbedre vitenskapelig resonnement og gi konstruktiv tilbakemelding (Rönnebeck et al., 2016). For eksempel er det viktig for elevene å delta i diskusjoner rundt eksperimenter de har gjort. Dette inngår også som et av spørsmålene som måler den latente variabelen, «utforskende arbeidsmåter». I tillegg kan det å utføre eksperimenter i seg selv være en sosial aktivitet. I utforskende samtaler blir "alle bedt om å gjøre rede for sine begrunnelser" og "utfordringer og alternativer blir gjort eksplisitte og blir forhandlet frem» (Mercer et al., 2004, s. 362). Dette reflekteres også i et av spørsmålene for den latente variabelen "utforskende arbeidsmåter», som dreier seg om hvorvidt læreren ber elevene forklare sine egne ideer og tanker. Ved å engasjere elever i spørsmålsformulering, datainnsamling, og kunnskapsbygging (Knain \& Kolstø, 2019) vil utforskende arbeidsmåter benytte seg av alle de fire domenene innen vitenskapelig kunnskap som er grunnleggende for læring i naturfag.

Det at de forskjellige domenene av vitenskapelig kunnskap blir reflektert i spørsmålene relatert til «utforskende arbeidsmåter», kan være noe av grunnen til at denne variabelen hadde en positiv sammenheng med elevenes motivasjon og prestasjoner i naturfag.

Hvordan kan så utforskende arbeidsmåter bidra til å styrke elevenes faglige motivasjon? Selvbestemmelsesteorien (Deci \& Ryan, 2000, 2008), hvor autonomi, kompetanse gjennom mestring og tilhørighet er de sentrale begrepene, ble benyttet som teoretisk rammeverk for å forklare sammenhengene mellom motivasjon og både utforskende arbeidsmåter og frekvensen av eksperimenter. Gjennom å legge til rette for autonomi og mestring og stimulere til sosial interaksjon, noe som inngår i utforskende arbeidsmåter, er læreren med på å motivere elevene (Areepattamannil et al., 2020; Palmer, 2009; Wu \& Wu, 2020). I spørsmålene som brukes i den foreliggende studien for å måle utforskende arbeidsmåter og eksperimenter, blir disse tre aspektene ved selvbestemmelsesteorien adressert. Gjennom bruk av utforskende arbeidsmåter blir elevene stimulert kognitivt og får en følelse av mestring (kompetanse). De er dessuten med på å planlegge forsøk (autonomi), de samarbeider under forsøk og diskuterer forsøkene i etterkant (tilhørighet). Tidligere forskning har funnet at utforskende arbeidsmåter har en klar positiv påvirkning på elevers motivasjon (Aditomo \& Klieme, 2020; Adler et al., 2018; Palmer, 2009; Wu $\& \mathrm{Wu}, 2020)$. De presenterte funnene samsvarer godt med dette, og viser at det også gjelder for norske elever. 


\subsubsection{Begrensninger for analysene}

I denne studien ble tverrsnittsdata benyttet, noe som betyr at det ikke kan trekkes kausale slutninger. I tillegg benyttes rapportering fra elevene for å måle lærerens undervisning. Direkte observasjoner av naturfagtimene kunne gitt et mer nyansert bilde. Likevel vil slutningene som trekkes i denne studien, ha høy validitet fordi funnene relateres til tidligere forskning og til vitenskapelige teorier. I tillegg holder både designet og kvaliteten på dataene høy kvalitet, og det benyttes robuste metoder (flernivå strukturell ligningsmodellering) som er teoribyggende og gir reliable og valide resultater (Heck \& Thomas, 2015; Hox et al., 2017).

Konstruktvaliditeten av utforskende arbeidsmåter skal være høy i og med at denne bygger på tidligere forskning. Likevel kan det være en mulighet for underrepresentasjon av konstruktet, det vil si at ikke alle aspekter av begrepet er dekket. Begrepet kunne muligens blitt ytterligere dekket og belyst dersom elevene hadde fått flere spørsmål knyttet til utforskende arbeidsmetoder. Dette er imidlertid en utfordring som ikke er spesielt for TIMSS og den foreliggende studien, men som er langt mer generell. Etter hvert som nye forskningsstudier lager nye konstrukter basert på tidligere teori, bygges ny kunnskap om utforskende arbeidsmåter. I dag er det verken enighet om begrepet eller operasjonaliseringen, og det skyldes blant annet at begrepet er svært bredt og inkluderer mange forskjellige aspekter (Knain \& Kolstø, 2019). I denne studien bygger konstruktet på en anerkjent, teoretisk modell av Rönnebeck et al. (2016). Hele elevspørreskjemaet har dessuten blitt pilotert og deretter evaluert teoretisk og psykometrisk før gjennomføringen av selve hovedundersøkelsen. Slutningene som trekkes i denne analysen, anses derfor som både valide og reliable.

\subsubsection{Implikasjoner, bidrag og videre forskning}

Det er gjennomført få studier på utforskende arbeidsmetoder med representative utvalg, og hvor dataene har gjennomgått så mange og grundige kvalitetssjekker som i den foreliggende analysen. Studiens viktigste bidrag til forskningsfronten er at resultatene kan generaliseres til nasjonalt nivå, og at kvaliteten til både dataene, metoden og analysene bidrar til valide slutninger.

Det er videre få studier som har undersøkt påvirkningen av utforskende arbeidsmetoder på både motivasjon og prestasjoner. De fleste studier har hovedsakelig undersøkt relasjonen til motivasjon (Areepattamannil et al., 2020; Wu \& Wu, 2020), og et fåtall har undersøkt sammenhenger med prestasjoner (Cairns, 2019; Oliver et al., 2019). Denne studien er derfor med på å bygge kunnskap om betydningen av utforskende arbeidsmåter for både motivasjon og prestasjoner. Derfor 
anses funnene som viktige, og som svært interessante og relevante for lærerutdanningen, skoleeiere, utdanningspolitikk, lærere og læreplanutvikling.

Den kurvelineære sammenhengen mellom eksperimenter og prestasjoner har blitt påvist i en tidligere studie basert på TIMSS 2015, med data fra lærerspørreskjemaet (Teig et al., 2018). Studien i dette kapitlet repliserte dette funnet, men er basert på TIMSS 2019, og med data fra elevspørreskjemaet. Dette samsvaret viser at funnet er robust. Fremtidige lignende studier av naturfag bør derfor ta hensyn til dette funnet og undersøke hvorvidt relasjonene mellom eksperimenter og prestasjoner er kurvelineære eller lineære. Funnet bør også være viktig for lærere og for lærerutdanningen. Det viser at selv om det er verdifullt for elever å gjøre eksperimenter, så vil for høy frekvens av eksperimenter kunne påvirke læringen negativt. Dette kan skyldes at eksperimenter tar mye tid, og ofte krever mye forkunnskap.

En utfordring for fremtidige forskningsstudier er å utdype betydningen av eksperimenter. Det er nærliggende å tro at mange andre faktorer kan påvirke relasjonen mellom eksperimenter og prestasjoner, for eksempel lærerens kompetanse, type eksperiment, veiledning og tilbakemelding fra læreren underveis, etterarbeid og diskusjoner relatert til hva man kan lære av eksperimentet (Rönnebeck et al., 2016).

\subsubsection{Konklusjon}

De viktigste funnene i denne studien var at utforskende arbeidsmåter og frekvensen av eksperimenter hadde en positiv sammenheng med elevenes motivasjon og prestasjoner på klassenivå. Disse funnene er relevante for både forskningsfeltet og skolens virksomhet. Funnene bygger opp om den positive betydningen av bruk av utforskende arbeidsmåter i naturfag og viser at dette fremmer elevers motivasjon og læringsutbytte.

\section{REFERANSER}

Abd-El-Khalick, F., Boujaoude, S., Duschl, R.A., Lederman, N.G., Mamlok-Naaman, R., Hofstein, A., Niaz, M., Treagust, D. \& Tuan, H.-l. (2004). Inquiry in science education: International perspectives. Science Education, 88(3), 397-419.

Aditomo, A. \& Klieme, E. (2020). Forms of inquiry-based science instruction and their relations with learning outcomes: Evidence from high and low-performing education systems. International Journal of Science Education, 1-22.

Adler, I., Schwartz, L., Madjar, N. \& Zion, M. (2018). Reading between the lines: The effect of contextual factors on student motivation throughout an open inquiry process. Science Education, 102(4).

Alfieri, L., Brooks, P.J., Aldrich, N.J. \& Tenenbaum, H.R. (2011). Does discovery-based instruction enhance learning? Journal of Educational Psychology, 103(1), 1-18. 
American Association for the Advancement of Science. (1994). Science for all americans: Project 2061. Oxford University Press.

Areepattamannil, S., Cairns, D. \& Dickson, M. (2020). Teacher-Directed Versus Inquiry-Based Science Instruction: Investigating Links to Adolescent Students' Science Dispositions Across 66 Countries. Journal of Research in Science Teacher.

Blanchard, M.R., Southerland, S.A., Osborne, J.W., Sampson, V.D., Annetta, L.A. \& Granger, E. M. (2010). Is inquiry possible in light of accountability?A quantitative comparison of the relative effectiveness of guided inquiry and verification laboratory instruction. Science education, 94(4), 577-616.

Bybee, R.W., Taylor, J.A., Gardner, A., Van Scotter, P., Powell, J.C., Westbrook, A. \& Landes, N. (2006). The BSCS 5E instructional model: Origins and effectiveness. Colorado Springs, Co:

BSCS, 5, 88-89. Hentet fra http://www.fremonths.org/ourpages/auto/2008/5/11/ 1210522036057/bscs5efullreport2006.pdf

Cairns, D. (2019). Investigating the relationship between instructional practices and science achievement in an inquiry-based learning environment. International Journal of Science Education, 41(15), 2113-2135.

Chin, C. \& Brown, D.E. (2000). Learning in science: A comparison of deep and surface approaches. Journal of research in science teaching, 37(2), 109-138.

Constantinou, C.P., Tsivitanidou, O.E. \& Rybska, E. (2018). What is inquiry-based science teaching and learning? I Tsivitanidou O., Gray P., Rybska E., Louca L., Constantinou C. (Red.), Professional development for inquiry-based science teaching and learning (s. 1-23). Springer International Publishing.

Crawford, B.A. (2014). From inquiry to scientific practices in the science classroom. I N.G. Lederman \& S.K. Abell (Red.), Handbook of research on science education (s. 529-556). Routledge.

Deci, E.L. \& Ryan, R.M. (2000). The "what" and "why" of goal pursuits: human needs and the self-determination of behavior. Psychological Inquiry, 11(4), 227-268.

Deci, E.L. \& Ryan, R.M. (2008). Self-determination theory: A macrotheory of human motivation, development, and health. Canadian Psychology/Psychologie canadienne, 49(3), 182-185.

Duschl, R.A. (2003). Assessment of inquiry. I J.M. Atkin \& J. Coffey (Red.), Everyday assessment in the science classroom (s. 41-59). NSTA Press.

Duschl, R.A. (2008). Science education in three-part harmony: Balancing conceptual, epistemic, and social learning goals. Review of Research in Education, 32, 268-291.

Eccles, J.S. \& Wigfield, A. (2002). Motivational beliefs, values, and goals. Annual Review of Psychology, 53(1), 109-132.

Estrella, G., Au, J., Jaeggi, S.M. \& Collins, P. (2018). Is inquiry science instruction effective for English language learners? A meta-analytic review. AERA Open, 4(2), 1-23.

Furtak, E.M. \& Penuel, W.R. (2019). Coming to terms: Addressing the persistence of "hands-on" and other reform terminology in the era of science as practice. Science education, 103(1), 167-186.

Furtak, E.M., Seidel, T., Iverson, H. \& Briggs, D.C. (2012). Experimental and quasi-experimental studies of inquiry-based science teaching. Review of Educational Research, 82(3), 300-329.

Gee, K.A. \& Wong, K.K. (2012). A cross national examination of inquiry and its relationship to student performance in science: Evidence from the Program for International Student Assess- 
ment (PISA) 2006. International Journal of Educational Research, 53, 303-318.

Haug, B.S. \& Ødegaard, M. (2014). From words to concepts: Focusing on word knowledge when teaching for conceptual understanding within an inquiry-based science setting. Research in Science Education, 44(5), 777-800.

Heck, R.H. \& Thomas, S.L. (2015). An introduction to multilevel modeling techniques: MLM and SEM approaches using Mplus. Routledge.

Hox, J.J., Moerbeek, M. \& van de Schoot, R. (2017). Multilevel analysis: Techniques and applications. Routledge.

Hu, L.-t. \& Bentler, P.M. (1999). Cutoff criteria for fit indexes in covariance structure analysis: Conventional criteria versus new alternatives. Structural Equation Modeling: A Multidisciplinary Journal, 6(1), 1-55.

Hubber, P., Tytler, R. \& Chittleborough, G. (2018). Representation Construction: A Guided Inquiry Approach for Science Education. I R. Jorgensen \& K. Larkin (Red.), STEM Education in the Junior Secondary: The State of Play (s. 57-89). Springer Singapore.

Kaarstein, H., Radišić, J., Lehre, A.-C. W., Nilsen, T. \& Bergem, O.K. (2020). TIMSS 2019. Kortrapport. Institutt for lærerutdanning og skoleforskning, Universitetet i Oslo.

Knain, E., Fredlund, T. \& Furberg, A. (2021). Exploring student reasoning and representation construction in school science through the lenses of social semiotics and interaction analysis. Research in Science Education, 51(1), 93-111.

Knain, E. \& Kolstø, S.D. (2019). Utforskende arbeidsmåter - en oversikt. I E. Knain \& S.D. Kolstø (Red.), Elever som forskere i naturfag (s. 127-163).

Krajcik, J.S. \& Sutherland, L.M. (2010). Supporting students in developing literacy in science. Science, 328(5977), 456-459.

Kunnskapdepartmentet. (2010). Realfag for framtida. Oslo: Utdanningsdirektoratet. Hentet fra https://www.regjeringen.no/globalassets/upload/kilde/kd/nyh/2006/0014/ddd/pdfv/290281strategiplan_for_realfagene.pdf

Kunnskapdepartmentet. (2015). Tett på realfag. Nasjonal strategi for realfag $i$ barnehagen og grunnopploringen (2015-2019). Utdanningsdirektoratet. Hentet fra https://www.regjeringen.no/contentassets/869faa81d1d740d297776740e67e3e65/kd_realfagsstrategi.pdf

Lavonen, J. \& Laaksonen, S. (2009). Context of teaching and learning school science in Finland: Reflections on PISA 2006 results. Journal of Research in Science Teaching, 46(8), 922-944.

Lazonder, A.W. \& Harmsen, R. (2016). Meta-analysis of inquiry-based learning: Effects of guidance. Review of Educational Research, 86(3), 681-718.

Lederman, N.G. (2019). Contextualizing the relationship between nature of scientific knowledge and scientific inquiry. Science \& Education, 28(3-5), 249-267.

Lee, E.A. \& Brown, M.J. (2018). Connecting inquiry and values in science education. Science \& Education, 27(1), 63-79.

Lüdtke, O., Trautwein, U., Kunter, M. \& Baumert, J. (2007). Reliability and agreement of student ratings of the classroom environment: A reanalysis of TIMSS data. Learning Environments Research, 9(3), 215-230.

Marsh, H.W., Ludtke, O., Nagengast, B., Trautwein, U., Morin, A.J.S., Abduljabbar, A.S. \& Koller, O. (2012). Classroom climate and contextual effects: Conceptual and methodological issues in the evaluation of group-level effects. Educational Psychologist, 47(2), 106-124. 
Martin, M.O., Mullis, I.V.S., Foy, P. \& Hooper, M. (2016). TIMSS 2015 international results in science. Boston, MA: Boston College, TIMSS \& PIRLS International Study Center.

Martin, M.O., von Davier, M., Mullis, I.V.S. \& Foy, P. (2020). Methods and Procedures: TIMSS 2019 Technical Report. Boston College: TIMSS \& PIRLS International Study Center.

Mercer, N., Dawes, L., Wegerif, R. \& Sams, C. (2004). Reasoning as a scientist: Ways of helping children to use language to learn science. British educational research journal, 30(3), 359-377.

Minner, D.D., Levy, A.J. \& Century, J. (2010). Inquiry-based science instruction-what is it and does it matter? Results from a research synthesis years 1984 to 2002. Journal of research in science teaching, 47(4), 474-496.

Mullis, I.V.S. \& Martin, M.O. (2017). TIMSS 2019 Science Framework. Hentet fra Boston College, TIMSS \& PIRLS International Study Center website: http://timssandpirls.bc.edu/timss2019/ frameworks/

Mullis, I.V.S., Martin, M.O., Foy, P., Kelly, D.L. \& Fishbein, B. (2020). TIMSS 2019 International Results in Mathematics and Science. Hentet fra Boston College, TIMSS \& PIRLS International Study Center website: https://timssandpirls.bc.edu/timss2019/international-results/

Muthén, L.K. \& Muthén, B.O. (1998-2018). Mplus version 8.2. Muthén \& Muthén.

National Research Council. (2000). Inquiry and the national science education standards: A guide for teaching and learning. National Academies Press.

National Research Council. (2007). Taking science to school: Learning and teaching science in grades K-8. National Academies Press.

National Research Council. (2012). A framework for K-12 science education: Practices, crosscutting concepts, and core ideas. National Academies Press.

NOU (2015). Fremtidens skole - Fornyelse av fag og kompetanser. Norges offentlige utredninger (NOU).

Ødegaard, M., Kjærnsli, M., Karlsen, S., Kersting, M., Lunde, M.L.S., Olufsen, M. \& Sæleset, J. (2021). Tett på naturfag i klasserommet. Hentet fra https://www.uv.uio.no/ils/forskning/prosjekter/lissi-laring-naturfag/lissi_kortrapport.pdf

OECD (2016). PISA 2015 assessment and analytical framework: Science, reading, mathematic and financial literacy. Paris: OECD Publishing.

Oliver, M., McConney, A. \& Woods-McConney, A. (2019). The efficacy of inquiry-based instruction in science: A comparative analysis of six countries using PISA 2015. Research in Science Education. https://doi.org/10.1007/s11165-019-09901-0

Palmer, D. (2009). Student interest generated during an inquiry skills lesson. Journal of research in science teaching, 46(2), 147-165.

Rivet, A.E. \& Krajcik, J.S. (2008). Contextualizing instruction: Leveraging students' prior knowledge and experiences to foster understanding of middle school science. Journal of research in science teaching, 45(1), 79-100.

Rocard, M., Csermely, P., Jorde, D., Dieter Lenzen, Walberg-Henriksson, H. \& Hemmo, V. (2007). Science education now: A renewed pedagogy for the future of europe. Hentet fra https:// ec.europa.eu/research/science-society/document_library/pdf_06/report-rocard-on-scienceeducation_en.pdf

Rönnebeck, S., Bernholt, S. \& Ropohl, M. (2016). Searching for a common ground-a literature review of empirical research on scientific inquiry activities. Studies in Science Education, 52(2), 161-197. 
Rönnebeck, S., Nielsen, J.A., Olley, C., Ropohl, M. \& Stables, K. (2018). The teaching and assessment of inquiry competences. I J. Dolin \& R. Evans (Red.), Transforming assessment: Through an interplay between practice, research and policy (s. 27-52). Springer International Publishing. Ryan, R.M. \& Deci, E.L. (2000). Self-determination theory and the facilitation of intrinsic motivation, social development, and well-being. American psychologist, 55(1), 68-78.

Ryan, R.M. \& Deci, E.L. (2020). Intrinsic and extrinsic motivation from a self-determination theory perspective: Definitions, theory, practices, and future directions. Contemporary Educational Psychology, 61, 101860.

Sadler, T.D., Barab, S.A. \& Scott, B. (2007). What do students gain by engaging in socioscientific inquiry? Research in Science Education, 37(4), 371-391.

Schwab, J.J. (1962). The teaching of science as enquiry. I J.J. Schwab \& P.F. Brandwein (Red.), The teaching of science. Harvard University Press.

Teig, N. (2019). Scientific inquiry in TIMSS and PISA 2015: Inquiry as an instructional approach and the assessment of inquiry as an instructional outcome in science (Doktoravhandling). Universitetet i Oslo. Hentet fra https://www.duo.uio.no/handle/10852/71649

Teig, N. \& Scherer, R. (2016). Bringing formal and informal reasoning together - a new era of assessment? Frontiers in psychology, 7. Hentet fra https://doi.org/10.3389/fpsyg.2016.01097

Teig, N., Scherer, R. \& Nilsen, T. (2018). More isn't always better: The curvilinear relationship between inquiry-based teaching and student achievement in science. Learning and Instruction, 56, 20-29.

Teig, N., Scherer, R. \& Nilsen, T. (2019). I know I can, but do I have the time? The role of teachers' self-efficacy and perceived time constraints in implementing cognitive-activation strategies in science. Frontiers in psychology, 10(1697). Hentet fra https://doi.org/10.3389/fpsyg.2019.01697

Utdanningsdirektoratet (2006). Læreplan i naturfag (NAT1-03). Hentet fra https://www.udir.no/ k106/NAT1-03?lplang=http://data.udir.no/kl06/nob

Utdanningsdirektoratet (2019). Dybdelæring. Hentet fra https://www.udir.no/laring-og-trivsel/ dybdelaring/

Utdanningsdirektoratet (2020). Læreplan i naturfag (NAT01-04). Hentet fra https://www.udir.no/ lk20/nat01-04

von Davier, M., Gonzalez, E. \& Mislevy, R. (2009). What are plausible values and why are they useful. IERI monograph series, 2(1), 9-36.

Wu, P.-H. \& Wu, H.-K. (2020). Constructing a model of engagement in scientific inquiry: investigating relationships between inquiry-related curiosity, dimensions of engagement, and inquiry abilities. Instructional Science, 48(1), 79-113.

Zhang, F. \& Bae, C.L. (2020). Motivational factors that influence student science achievement: a systematic literature review of TIMSS studies. International Journal of Science Education, 42(17), 2921-2944.

Ødegaard, M., Kjærnsli, M., Karlsen, S., Kersting, M., Suhr Lunde, M.L., Olufsen, M. \& Sæleset, J. (2021). Tett på naturfag i klasserommet. Kortrapport fra studien Linking Instruction in Science \& Student Impact. Hentet fra: https://www.udir.no/contentassets/ 0fc2b0772543408f9767bf8a9a146f2f/klasseromsstudier-i-naturfag_rapport-ils.pdf 